\title{
A Poststorage Burst of 6-Methyl-5-hepten-2-one (MHO) May Be Related to Superficial Scald Development in 'Cortland' Apples
}

\author{
Nazir Mir, ${ }^{1}$ Rufino Perez, ${ }^{2}$ and Randolph M. Beaudry ${ }^{3}$ \\ Department of Horticulture, Michigan State University, East Lansing, MI 48824
}

\begin{abstract}
Additional Index words. Malus $\times$ domestica, superficial scald, $\alpha$-farnesene, ketone, storage, disorder.
Abstract. 'Cortland' apples (Malus $\times$ domestica Borkh.), either untreated or treated with diphenylamine (DPA), were stored for 120 days in air at $0^{\circ} \mathrm{C}$. Peel samples were taken from these fruit immediately after storage, placed in glass vials and incubated for 48 hours, or were isolated from fruit held 2 to 72 hours at $22{ }^{\circ} \mathrm{C}$ and incubated in the vials for 2 hours. Emission of 3,7,11-trimethyldodeca-1,3(E),6(E),10-tetraene, known as trans,trans- $\alpha$-farnesene, or simply $\alpha$-farnesene, and its oxidation product, MHO, were measured in the vial headspace. $\alpha$-Farnesene content in the gas phase of vials with peel samples reached a maximal level 2 hours after vials were sealed and was higher in DPA-treated than untreated fruit. The content of $\alpha$-farnesene in the vial headspace remained unchanged for DPA-treated fruit peel during the 2-day holding period. However, $\alpha$-farnesene declined rapidly after 10 hours incubation for control samples. Incubating peel samples of control fruit under $\mathrm{N}_{2}$ atmosphere prevented the decline in $\alpha$-farnesene. The MHO release by the peel of control fruit was rapid during the first 2 hours and continued to increase for 24 hours. In contrast, the MHO released from DPA-treated fruit peels was 8000 -fold lower than from peel samples of control fruit. The increase in vapor phase MHO was concomitant with peel browning in controls. For whole fruit held at $22^{\circ} \mathrm{C}$ for 2 to 72 hours, cumulative MHO release from fruit peels followed a pattern that was similar to the pattern of superficial scald development in these fruit.
\end{abstract}

Superficial scald is a postharvest physiological disorder that develops during storage of most commercially grown cultivars of apple (Emongor et al., 1994; Ingle and D'Souza, 1989; Wilkinson and Fidler, 1973). The damage caused by the disorder occurs primarily in the outer four to five plastid-bearing cell layers of the hypodermis and is manifested as skin browning (Bain and Mercer, 1963) with some pitting if the damage is severe (Emongor et al., 1994). Scald symptom development is accelerated when the stored fruit are warmed for 3 to $7 \mathrm{~d}$ following low-temperature storage (Brooks et al., 1919).

$\alpha$-Farnesene, a sesquiterpene hydrocarbon, accumulates and then declines in the peel of apple during low temperature storage and is present primarily in the trans-trans configuration (Murray, 1969). This compound has been implicated in the induction of scald in these fruit (Anet, 1969; 1972; Huelin and Coggiola, 1970a, 1970b, 1970c; Huelin and Murray, 1966; Ingle and D'Souza, 1989; Murray et al., 1964). Fruit cultivars that produce less $\alpha$ farnesene are less likely to develop superficial scald during storage (Huelin and Coggiola, 1968; Whitaker et al., 1997) although treatments that reduce $\alpha$-farnesene accumulation do not always reduce scald severity (Meigh and Filmer, 1969). However, $\alpha-$ farnesene by itself has failed to induce or accelerate scald-like symptoms in apple (Huelin and Coggiola, 1970c), and it has been suggested that $\alpha$-farnesene oxidation products are likely to lead to scald development (Huelin and Coggiola, 1970a).

The main products of $\alpha$-farnesene oxidation in vivo are isomers of 2,6,10-trimethyl dodeca-2,7,9,11,tetraen-6-ol, commonly called conjugated trienols (CTs), of which 7(E),9(E) is the most abundant

\footnotetext{
Received for publication 5 May 1998. Accepted for publication 13 Nov. 1998. Research conducted at the Postharvest Technology and Physiology Laboratory, Horticulture Department, Michigan State University, East Lansing, MI 48824. Use of trade names does not imply endorsement of the products named nor criticism of similar ones not named. The cost of publishing this paper was defrayed in part by the payment of page charges. Under postal regulations, this paper therefore must be hereby marked advertisement solely to indicate this fact.

${ }^{1}$ Postdoctoral research associate.

${ }^{2}$ Graduate student.

${ }^{3}$ Associate professor, postharvest biology and technology.
}

component in 'Granny Smith' (Rowan et al., 1995) and 'Delicious' (Whitaker et al., 1997) apples. Scald symptom development is correlated with the accumulation of CTs (Huelin and Coggiola, 1970c), but the causal agents that lead to the disorder development have not been elucidated.

Lipophilic volatile compounds continuously produced during low-temperature storage partition into the cuticle and would potentially accumulate to high levels (Huelin and Coggiola, 1970b). Huelin and Coggiola (1968) have suggested, in fact, that $\alpha$ farnesene oxidation is prevented while it is in the living cell and that it is only after $\alpha$-farnesene is excreted into the waxy portion of the cuticle that oxidation occurs. MHO, one of the volatile oxidation products of $\alpha$-farnesene (Anet, 1972; Filmer and Meigh, 1969) is also a highly lipophilic compound as judged by its high partition coefficient into lipophilic polymers (Song et al., 1997). Provided $\alpha$-farnesene and/or MHO have a negative heat of solution in apple cuticles and/or epicuticular waxes, which is a common feature for readily condensable organic vapors into lipophilic materials (Brunauer, 1945), one would anticipate a transient rise in the emission of $\alpha$-farnesene and MHO if low-temperature-stored fruit are transferred to room temperature. Additionally, the transition of fruit having considerable $\alpha$-farnesene and CTs into warmer temperatures would likely enhance the oxidation process, further suggesting the possibility of a poststorage burst in MHO. A rapid oxidation of $\alpha$-farnesene and/or CTs may be related to the rapid scald symptom development observed when susceptible fruit are removed from cold storage and held for 3 to $7 \mathrm{~d}$ at room temperature (Brooks et al., 1919).

Our objective was to obtain a relative measure of $\alpha$-farnesene and MHO content in the peel of 'Cortland' apples stored for $120 \mathrm{~d}$ at $0{ }^{\circ} \mathrm{C}$ and warmed to $22{ }^{\circ} \mathrm{C}$. We have used excised peel samples placed in small vials and measured the concentration of these compounds in the gas phase. Using this technique, one study was conducted to relate the effect of DPA and $\mathrm{O}_{2}$ on $\alpha$-farnesene and MHO contents. In a second study, we determined volatile evolution from peel samples removed from whole fruit during warming and related MHO production to scald incidence. 


\section{Materials and Methods}

Fruit Material. 'Cortland' apples were harvested 25 Sept. in 1996 from the Clarksville Horticulture Experiment Station, Clarksville, Mich. About 400 fruit were immediately brought to the laboratory and were kept overnight at $22{ }^{\circ} \mathrm{C}$ to equilibrate with ambient temperature. After transport to the laboratory, a 1-mL gas sample was removed from each of 10 representative fruit and analyzed for ethylene using a gas chromatograph (Carle AGC Series 400, Hach Co., Loveland, Colo.) fitted with an FID and a 2 $\mathrm{m}$ long column packed with activated alumina. Ethylene concentrations were calculated relative to a certified ethylene standard (Matheson Gas Products, Chicago, Ill.) with a concentration of $0.979 \mu \mathrm{L} \cdot \mathrm{L}^{-1}$. The fruit were judged to be at a mature, but preclimacteric stage of development, using the criteria of Beaudry et al. (1993) in that $<20 \%$ of the fruit had an internal ethylene concentration $>0.2 \mu \mathrm{L} \cdot \mathrm{L}^{-1}$.

Half of the fruit were dipped into a solution of $5.9 \mathrm{mmol} \cdot \mathrm{L}^{-1}$ $(1000 \mathrm{ppm})$ DPA. The DPA-treated fruit were air dried for $\approx 6 \mathrm{~h}$ at $22{ }^{\circ} \mathrm{C}$. DPA-treated and nontreated (control) fruit were kept separately in plastic buckets in refrigerated air (RA) storage at $0^{\circ} \mathrm{C}$ in air and at a relative humidity of $>95 \%$ for $120 \mathrm{~d}$.

Peel incubation Study. After storage, three DPA-treated and three control fruit were transferred to a cold room maintained at 4 ${ }^{\circ} \mathrm{C}$. Peel samples $(1 \mathrm{~mm}$ in width $\times 10 \mathrm{~mm}$ in length), $\approx 0.5$ to $1 \mathrm{~mm}$ thick, were carefully removed from the fruit using a fine razor blade. About $50 \mathrm{mg}$ of the peel tissue from each fruit was immediately sealed in 2-mL glass vials capped with a Teflon-lined septum. The tissue from each fruit was kept in separate vials. Care was taken to complete the peeling and sealing operations in less than $45 \mathrm{~s}$. The vials were warmed to $22{ }^{\circ} \mathrm{C}$ and $\alpha$-farnesene and MHO content in the head space of the vial were measured over a period of $48 \mathrm{~h}$.

The $\mathrm{O}_{2}$ requirement for oxidation of $\alpha$-farnesene and the accumulation of $\mathrm{MHO}$ was tested for peel tissues of non-DPA treated fruit. Peel samples from 6 different fruit were placed in separate vials at $4^{\circ} \mathrm{C}$. The atmosphere in the vials was purged with $\mathrm{N}_{2}$ until $\mathrm{O}_{2}$ could no longer be detected $\left(<100 \mu \mathrm{L} \cdot \mathrm{L}^{-1}\right) . \mathrm{O}_{2}$ presence was measured using $0.1-\mathrm{mL}$ gas samples injected into the carrier gas $\left(\mathrm{N}_{2}, 100 \mathrm{~mL} \cdot \mathrm{min}^{-1}\right)$ stream of a paramagnetic $\mathrm{O}_{2}$ analyzer (Series 1110, Servomex Co., Sussex, England), which could detect $\mathrm{O}_{2}$ levels as low as $100 \mu \mathrm{L} \cdot \mathrm{L}^{-1}$. MHO release from these samples was determined after $0,2,24$, and $48 \mathrm{~h}$ at $22^{\circ} \mathrm{C}$.

WhOLE FRUIT STUDY. Fifteen control fruit were transferred from $0^{\circ} \mathrm{C}$ storage to the laboratory at $22^{\circ} \mathrm{C}$. Peel samples were collected $2,24,36,48$, and $72 \mathrm{~h}$ after transfer of fruit and sealed in vials as described for the incubation study, however, the incubation duration was $2 \mathrm{~h}$. At each of the five sampling times, there were three replications, with the peel sample of each individual fruit $(\approx 50 \mathrm{mg})$ separately placed into 2-mL glass vials. Different fruit were used at each sampling time. The MHO emission data were empirically fitted using Table Curve 2D (Jandel Scientific Software, San Rafael, Calif.), which calculates best fit curves for data sets using over 8000 equations. Of these equations, a Weibull function was chosen that was determined to most accurately depict the time dependence of the MHO data based on visual inspection and the value of the coefficient of determination. The integral of the curve was calculated manually by partitioning the curve into 150 segments to estimate the shape of the curve describing the total MHO evolved as function of time.

Twenty-nine fruit from untreated control and 50 from DPAtreated fruit were held at $22{ }^{\circ} \mathrm{C}$ for $7 \mathrm{~d}$. Scald severity was rated daily for each fruit using a scale of 0 to 4 , with $0=$ no scald, $1=$
$<10 \%, 2=11 \%$ to $25 \%, 3=26 \%$ to $50 \%$, and $4=>50 \%$ surface area affected. A scald index was calculated as the sum of the products of the frequency of each rating and the rating value.

VOLATILE COLLECTION, SEPARATION, AND DETECTION. Volatiles were sampled by means of solid phase microextraction (SPME) use 1-cm-long fibers coated with a $100 \mu \mathrm{m}$ thick layer of polydimethylsiloxane (Supelco Co., Bellefonte, Penn.). Before using, the fibers were conditioned at $250{ }^{\circ} \mathrm{C}$ for $60 \mathrm{~min}$. SPME fibers were inserted into incubation vials and headspace volatiles were absorbed for $5 \mathrm{~min}$. Separation and detection was by gas chromatography (HP-6890, Hewlett Packard Co., Wilmington, Del.) and time-of-flight mass spectrometry (Pegasus II, LECO Corp., St. Joseph, Mich.), respectively, according to the method of Song et al. (1997). Identification and quantification of MHO was confirmed by comparison of the mass spectrum with that of an authentic reference standard (Sigma Chemical Company, St. Louis, Mo.) and spectra in the National Institute for Standards and Technology (NIST) mass spectra library, Search Version 1.5. The protocol for identification of $\alpha$-farnesene was similar to that of MHO. However, due to the presence of solvent, quantification could not be accomplished by SPME. $\alpha$-Farnesene extracted from apple peel was a gift from Dr. Bruce Whitaker, Beltsville Agricultural Research Center, USDA-ARS, Beltsville, Md.

\section{Results}

SCALD DEVELOPMENT DURING STORAGE AND POSTSTORAGE HOLDING. Untreated fruit had a scald index of 0.2 after $120 \mathrm{~d}$ RA storage. Scald index increased linearly from 0.2 at hour 0 of the poststorage

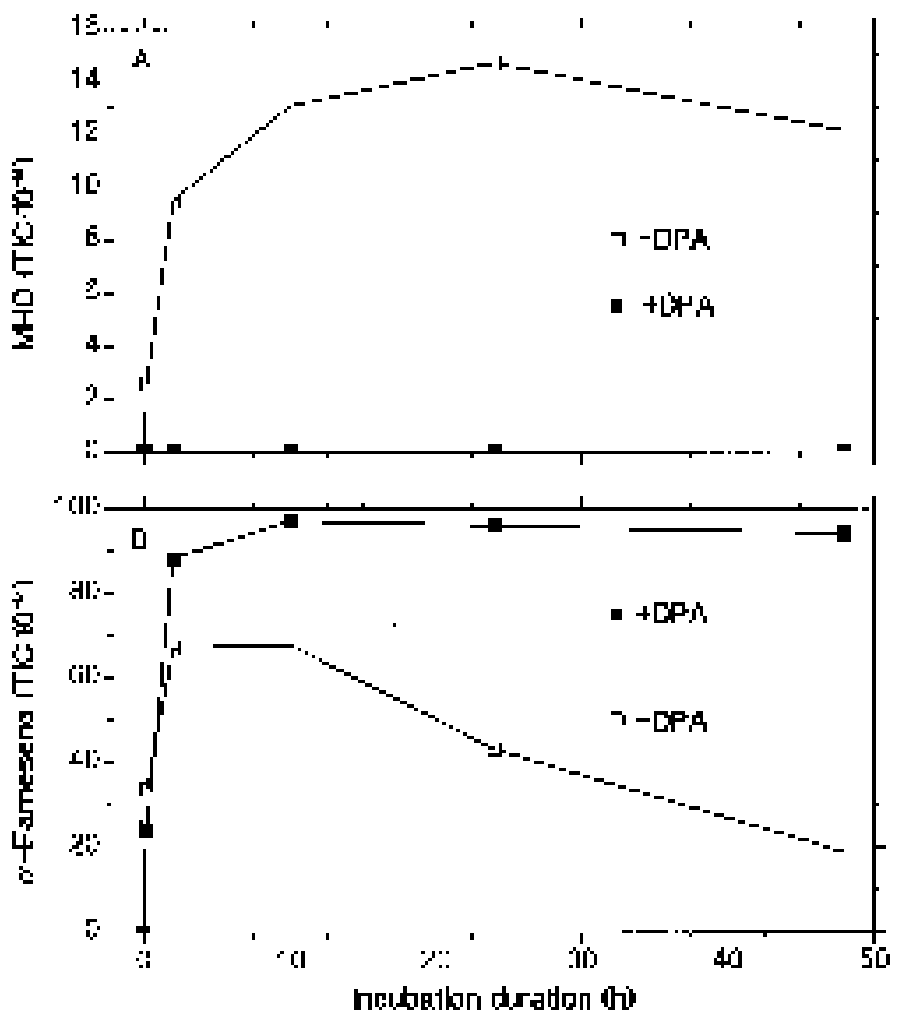

Fig. 1. MS total ion count (TIC) response to vapor phase $\mathrm{MHO}$ (A) and a-farnesene (B) content of 2-mL glass vials containing peel of 'Cortland' fruit that had been stored $120 \mathrm{~d}$ in air at $0^{\circ} \mathrm{C}$. The peel samples were removed from fruit while under refrigeration and incubated in vials for $48 \mathrm{~h}$ at $22^{\circ} \mathrm{C}$. DPA $\left(5.9 \mathrm{mmol} \cdot \mathrm{L}^{-1}\right)$ was applied at the time of harvest. The data at each sampling point are an average of 3 vials, each vial contained a peel sample from different fruit. Bars represent standard error of DPA-treated and untreated fruit. 
holding period to 3.8 at hour 72 of holding at $22^{\circ} \mathrm{C}$ and reached a maximum level (near 4) at 80 to $90 \mathrm{~h}$. Application of DPA at the time of harvest completely prevented the development of superficial scald both during RA storage and subsequent holding at $22^{\circ} \mathrm{C}$.

Peel incubation. $\alpha$-Farnesene release from the peel of fruit treated with DPA was rapid, reaching their maximal levels in 2 to $10 \mathrm{~h}$, after which the concentration remained steady (Fig. 1B). For control fruit peels, $\alpha$-farnesene release reached its maximum in 2 to $10 \mathrm{~h}$, but declined by $\approx 50 \%$ thereafter. When $\mathrm{O}_{2}$ was flushed from the atmosphere of the vials with $\mathrm{N}_{2}, \alpha$-farnesene release by control fruit peels increased rapidly in the first two h of holding and did not decline during the remainder of the $48 \mathrm{~h}$ incubation period (data not shown). Peel of fruit treated with DPA released $\approx 35 \%$ more $\alpha$-farnesene into the vial headspace than peel of nontreated fruit during the first $10 \mathrm{~h}$ of incubation.

The peel from control fruit released $\approx 8000$-fold more MHO into the vapor phase than peel from DPA-treated fruit (Fig. 1A). The MHO level in the vapor phase over DPA-treated fruit peels was barely detectable (MS response of $\approx 1600$ ). That of the untreated fruit increased for $\approx 24 \mathrm{~h}$ to a maximum (MS response of $\approx 14 \times 10^{6}$ ). When $\mathrm{O}_{2}$ was flushed from the vial atmosphere, $\mathrm{MHO}$ release by control fruit peels was similar to those incubated in $\mathrm{O}_{2}$ (data not shown). Peel samples of control fruit began to develop brown coloration after $24 \mathrm{~h}$ of incubation (data not shown). After $48 \mathrm{~h}$ incubation, the epidermal, hypodermal and cortex cells were completely brown. In contrast, no browning symptoms were visible in peel samples of DPA-treated fruit.

Poststorage hOLding OF WHOLE FRUIT. For whole fruit, MHO release from peel samples increased for $24 \mathrm{~h}$ and declined markedly after $48 \mathrm{~h}$ (Fig. 2). After $72 \mathrm{~h}, \mathrm{MHO}$ evolution was reduced to $\approx 1 / 8$ th of the amount at $24 \mathrm{~h}$. The data were fit to the Weibull function $a \cdot \exp \left(-\left(n+m^{(1 / d)}\right)^{d}+m\right) \cdot m^{(-m)} \cdot\left(n+m^{(1 / d)}\right)^{(d-1)}$, where $n=(x$ $-\mathrm{b}) / \mathrm{c}$ and $\mathrm{m}=(\mathrm{d}-1) / \mathrm{d}, \mathrm{x}=$ hours from time 0 and $\mathrm{a}, \mathrm{b}, \mathrm{c}$, and $\mathrm{d}$ are variables. The Weibull function is commonly used to describe the formation of reaction products from precursors (Bethea et al., 1975). Variable values for the best-fit equation were $\mathrm{a}=8040000$, $\mathrm{b}=24.5, \mathrm{c}=40.2, \mathrm{~d}=1.81\left(R^{2}=0.98\right)$. The curve describing the integral of $\mathrm{MHO}$ production suggested that cumulative $\mathrm{MHO}$ production by whole fruit initially increased nearly linearly with time and reached a maximum between 70 and $80 \mathrm{~h}$ of poststorage holding (Fig. 2) in a manner similar to scald development (Fig. 2, inset).

\section{Discussion}

The rapid development of superficial scald after RA storage in this study and its control by DPA is consistent with earlier studies (DeEll et al., 1996; Huelin and Coggiola, 1970a; 1970c; Lurie et al., 1989; Mir et al., 1998; Smock, 1955).

The oxidation products of $\alpha$-farnesene have been associated with the development of superficial scald (Anet, 1969, 1972; Huelin and Coggiola, 1970a, 1970b, 1970c). However, the pathway(s) resulting in the generation of scald-causing metabolites that originate from oxidation of $\alpha$-farnesene are not fully understood. High levels of CTs are correlated with the incidence of scald (Whitaker et al., 1997), but CTs also can decline after warming of stored fruit (Huelin and Coggiola, 1970c), when scald symptom development is most rapid, which suggests that the process of oxidation of the CTs, rather than their concentration, may be causally related to scald development.

Our data indicate that $\alpha$-farnesene was rapidly released from the excised fruit tissues. In the vial headspace of peels previously treated with DPA, the $\alpha$-farnesene attained stable levels in $\approx 2 \mathrm{~h}$,

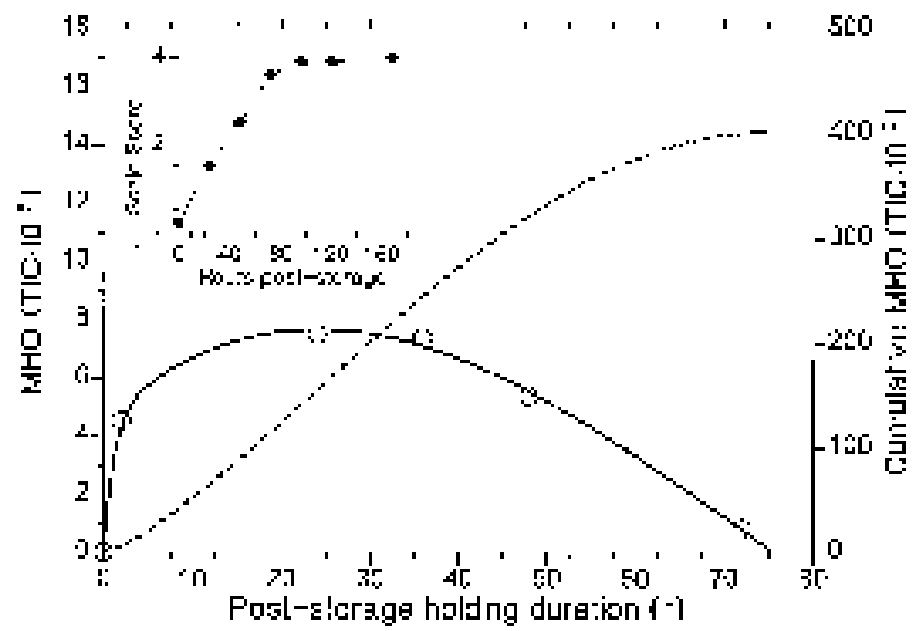

Fig. 2. MS total ion count (TIC) response to vapor phase MHO content of 2-mL glass vials containing peel of 'Cortland' fruit that had been stored $120 \mathrm{~d}$ in air at $0{ }^{\circ} \mathrm{C}$. The peel samples were from fruit held poststorage for $2,24,36,48$, and 72 $\mathrm{h}$ at $22{ }^{\circ} \mathrm{C}$. Peels were incubated in the vials for $2 \mathrm{~h}$ at $22{ }^{\circ} \mathrm{C}$. The data at each sampling point are an average of three vials; each vial contained a peel sample from a different fruit. The data were fit empirically using the Weibull function as indicated in text. The dotted line is the integral of the fitted line and represents an estimation of cumulative MHO production as a function of poststorage holding duration. Inset: superficial scald severity of non-DPA-treated 'Cortland' fruit stored $120 \mathrm{~d}$ in air at $0{ }^{\circ} \mathrm{C}$ as a function of poststorage holding duration at $22^{\circ} \mathrm{C}$.

likely as a result of the $\alpha$-farnesene in the peel tissue reaching equilibrium with that of the vial headspace. The decline in $\alpha$ farnesene in the vial headspace for untreated fruit after $10 \mathrm{~h}$ may therefore represent a decline in $\alpha$-farnesene content of the peel. We believe that the $\alpha$-farnesene was oxidized to CTs during this period in this system in control fruit, but that DPA continued to act as an antioxidant in DPA-treated fruit, preventing $\alpha$-farnesene oxidation during incubation. These results are supported by the findings of Huelin and Murray (1966) and a similar role in preventing $\alpha$ farnesene oxidation has been proposed for endogenous antioxidants (Barden and Bramlage, 1994; Meir and Bramlage, 1988). The lack of the decline in $\alpha$-farnesene in an $\mathrm{O}_{2}$-free environment further supports the possibility that the $\alpha$-farnesene decline in control vials was a result of its oxidation to CTs and other products.

The accumulation of $\alpha$-farnesene in the cuticular tissues and wax layer during low-temperature storage (Huelin and Coggiola, $1970 \mathrm{~b}$ ) could be due to continued biosynthesis of $\alpha$-farnesene and the lipophilic nature of the cuticle and waxes (Shutak and Christopher, 1960). MHO is also highly lipophilic (Song et al., 1997; 1998) and it may be that the burst in MHO is a result of its release from the cuticle due to a reduction in the sorption capacity of the cuticle for MHO with increasing temperature. Alternatively, the poststorage burst of $\mathrm{MHO}$ may reflect an enhancement in its synthesis in response to an increase in temperature.

It has recently been demonstrated that a large portion of the immediate oxidation products of CTs is MHO (Mir and Beaudry, unpublished results; Whitaker, personal communication). Thus, it is likely that $\alpha$-farnesene undergoes oxidation first to CTs, which further oxidize to MHO and other unidentified products. CTs are highly unstable compounds (Anet, 1969), whereas we have found MHO to be relatively stable in our gaseous standards in the present study (data not shown) and when used to evaluate SPME performance (Song et al., 1997, 1998). The minute amounts of MHO and no apparent scald detected in DPA-treated fruit further supports an association of CT oxidation and $\mathrm{MHO}$ production with superficial scald development. If CTs are the compounds primarily respon- 
sible for scald formation, then MHO may serve as a measure of their oxidation and associated tissue damage.

The similarity of the curve describing cumulative MHO production by whole fruit and that for scald symptom development provides a temporal relationship between $\mathrm{MHO}$ production and tissue damage that may indicate that MHO is causally linked to tissue damage. Direct involvement of $\mathrm{MHO}$ in scald development has not been shown, but was suggested as a possibility by Filmer and Meigh, (1969). The toxicity of MHO to apple tissues is unknown, but a damage similar to superficial scald consisting of skin browning in 'Delicious' occurred with the application of 2nonanone $\left(25 \mu \mathrm{L} \cdot \mathrm{L}^{-1}\right.$ in the vapor phase), a naturally occurring volatile ketone not present in apple but found in strawberry and raspberry (Leepipattanawit et al., 1997). Further studies are needed to delineate the roles of $\alpha$-farnesene, CTs and $\mathrm{MHO}$ in the mechanism of scald development.

\section{Literature Cited}

Anet, E.F.L.J. 1969. Autoxidation of $\alpha$-farnesene. Austral. J. Chem. 22:2403-2410.

Anet, E.F.L.J. 1972. Superficial scald, a functional disorder of stored apples. IX. Effect of maturity and ventilation. J. Sci. Food Agr. 23:763769.

Bain, J.M. and F.J. Mercer. 1963. The sub-microscopic cytology of superficial scald, a physiological disease of apples. Austral. J. Biol. Sci. 16:442-449.

Barden, C.L. and W.J. Bramlage. 1994. Relationships of antioxidants in apple peel to changes in $\alpha$-farnesene and conjugated trienes during storage, and to superficial scald development after storage. Postharvest Biol. Technol. 4:23-33.

Beaudry, R., P. Schwallier, and M. Lennington. 1993. Apple maturity prediction: An extension tool to aid in fruit storage decisions. HortTechnology 3(2):233-239.

Bethea, R.M., B.S. Duran, and T.L. Boullion. 1975. Statistical methods for engineers and scientists. Marcel Dekker, Inc., New York.

Brooks, C., J. Cooley, and D. Fisher. 1919. Nature and control of apple scald. J. Agr. Res. 18:211-240.

Brunauer, S. 1945. The kinetics of physical adsorption, p. 448-473. In: S. Brunauer (ed.). The adsorption of gases and vapors. Princeton Univ. Press, Princeton, N.J.

DeEll, J.R., R.K. Prange, and D.P. Murr. 1996. Chlorophyll fluorescence of 'Delicious' apples at harvest as a potential predictor of superficial scald development during storage. Postharvest Biol. Technol. 9:1-6.

Emongor, V.E., D.P. Murr, and E.C. Lougheed. 1994. Preharvest factors that predispose apples to superficial scald. Postharvest Biol. Technol. 4:289-300.

Filmer, A.A.E. and D.F. Meigh. 1969. Natural skin coating of the apple and its influence on scald in storage IV. Oxidation products of $\alpha$ farnesene. J. Sci. Food Agr. 20:188-190.

Huelin, F.E. and I.M. Coggiola. 1968. Superficial scald, a functional disorder of stored apples. IV. Effect of variety, maturity, oiled wraps and diphenylamine on the concentration of $\alpha$-farnesene in the fruit. J. Sci.
Food Agr. 19:297-301.

Huelin, F.E. and I.M. Coggiola. 1970a. Superficial scald, a functional disorder of stored apples. V. Oxidation of $\alpha$-farnesene and its inhibition by diphenylamine. J. Sci. Food Agr. 21:44-48.

Huelin, F.E. and I.M. Coggiola. 1970b. Superficial scald, a functional disorder of stored apples. VI. Evaporation of $\alpha$-farnesene from the fruit. J. Sci. Food Agr. 21:82-86.

Huelin, F.E. and I.M. Coggiola. 1970c. Superficial scald, a functional disorder of stored apples. VII. Effect of applied $\alpha$-farnesene, temperature and diphenylamine on scald and the concentration and oxidation of $\alpha$-farnesene in the fruit. J. Sci. Food Agr. 21:584-589.

Huelin, F.E. and K.E. Murray. 1966. $\alpha$-Farnesene in the natural coating of apples. Nature 210:1260-1261.

Ingle, M. and M.C. D'Souza. 1989. Physiology and control of superficial scald of apples. A review. HortScience 24:28-31.

Leepipattanawit, R, R.M. Beaudry, and R.J. Hernandez. 1997. Control of decay ion modified-atmosphere packages of sliced apples using 2nonanone vapor. J. Food Sci. 62:1043-1047.

Lurie, S., J. Klein, and R. Ben-Arie. 1989. Physiological changes in diphenylamine-treated 'Granny Smith' apples. Isr. J. Bot. 38:199-207.

Meigh, D.F. and A.A.E. Filmer. 1969. Natural skin coating of the apple and its influence on scald in storage III. $\alpha$-Farnesene. J. Sci. Food Agr. 20:139-143.

Meir, S. and W.J. Bramlage. 1988. Antioxidant activity in 'Cortland' apple peel and susceptibility to superficial scald after storage. J. Amer. Soc. Hort. Sci. 113:412-418.

Mir N., M. Wendorf, R. Perez, and R. Beaudry. 1998. Chlorophyll fluorescence in relation to superficial scald development in apple. J. Amer. Soc. Hort. Sci. 123:887-892.

Murray, K.E. 1969. $\alpha$-Farnesene: Isolation from the natural coatings of apple. Austral. J. Chem. 22:197-204.

Murray, K.E., F.E. Huelin, and J.B. Davenport 1964. Occurrence of farnesene in the natural coating of apples. Nature 204:80.

Rowan, D.D., J.M. Allen, S. Fielder, J.A. Spicer, and M.A. Brimble. 1995. Identification of conjugated triene oxidation products of $\alpha$-farnesene in apple skin. J. Agr. Food Chem. 43:2040-2045.

Shutak, V.G. and E.P. Christopher. 1960. Role of apple cuticle in development of storage scald on Cortland apples. Proc. Amer. Soc. Hort. Sci. 76:106-111.

Smock, R.M. 1955. A new method of scald control. Amer. Fruit Grower 75(11):20.

Song, J., B.D. Gardner, J.F. Holland, and R.M. Beaudry. 1997. Rapid analysis of volatile flavor compounds in apple fruit using SPME and GC/ time-of-flight mass spectrometry. J. Agr. Food Chem. 45:1801-1807.

Song, J., L. Fan, and R.M. Beaudry. 1998. Application of solid phase microextraction and gas chromatography/time-of-flight mass spectrometry for rapid analysis of flavor volatiles in tomato and strawberry fruit. J. Agr. Food Chem. 46:3721-3726.

Wilkinson, B.G. and J.C. Fidler. 1973. Physiological disorders, p. 67131. In: J.C. Fidler, B.G. Wilkinson, K.L. Edney, and R.O. Sharples (eds.). The biology of apple and pear storage. Commonw. Agr. Bur., Slough, England.

Whitaker, B.D., T. Solomos, and D.J. Harrison. 1997. Quantification of $\alpha-$ farnesene and its conjugated trienol oxidation products from apple peel by $\mathrm{C}_{18}$-HPLC with UV detection. J. Agr. Food Chem. 45:760-765. 